\title{
Meningkatkan Hasil Belajar Matematika Materi Himpunan Bilangan Dengan Model Pembelajaran Kooperatif Tipe Stad (Student Teams Achievement Divisions) Pada Siswa Kelas VII.4 Smpn 1 Praya Tahun Pelajaran 2018 /2019
}

\author{
Epat \\ Guru Matematika SMPN 1 Praya Kabupaten Lombok Tengah
}

\begin{abstract}
Abstrak. Penelitian ini bertujuan untuk meningkatkan pemahaman konsep matematika pada pokok bahasan himpunan siswa kelas VII.4 SMPN 1 Praya dengan penerapan model pembelajaran kooperatif tipe Student Teams Achievement Division (STAD) dan untuk hasil belajar Matematika dengan penerapan model pembelajaran kooperatif tipe STAD. Jenis penelitian ini adalah Penelitian Tindakan Kelas (PTK) yang dilakukan secara kolaboratif. Partisipan adalah siswa kelas VII.4 SMPN 1 Praya Tahun Pelajaran 2018 /2019, sebanyak 34 siswa dengan rincian 16 siswa laki-laki dan 18 siswa perempuan. Tindakan dilaksanakan dalam dua siklus. Instrumen yang digunakan untuk mengumpulkan data dalam penelitian ini berupa hasil belajar Matematika dengan model pembelajaran kooperatif tipe STAD, tes tertulis. Berdasarkan data yang diperoleh terlihat peningkatan hasil belajar yang signifikan, dimana pada siklus I diperoleh nilai rata - rata sebesar 66,55 kemudian meningkat pada siklus II nilai rata - rata diperoleh sebesar 81, 64 terjadi peningkatan sebesar 15 poin, kemudian pada siklus I jumlah siswa yang tuntas belajar sebanyak 21 orang atau dengan persentase sebesar $62 \%$, kemudian meningkat pada siklus II jumlah siswa yang tuntas belajar sebanyak 31 orang dengan persentase sebesar $91 \%$ terjadi peningkatan sebesar 53 poin, begitu juga dengan ketuntasan klasikal yang dipatok sebesar $\geq 80 \%$ juga sudah tercapai, sehingga penelitian ini dihentikan sampai pada siklus II. Dengan demikian dapat ditarik kesimpulan bahwa dengan penerapan model pembelajaran kooperatif tipe Student Team Achievement Divisions (STAD) dapat meningkatkan hasil belajar Matematika materi himpunan pada siswa kelas VII.4 SMPN 1 Praya Tahun Pelajaran 2018 /2019.
\end{abstract}

\section{Kata Kunci; Hasil Belajar, Himpunan, STAD (Student Teams Achievement Divisions)}

\section{PENDAHULUAN}

Matematika adalah mata pelajaran yang diajarkan mulai dari tingkat SD sampai sekolah tingkat menengah dan perguruan tinggi. Sampai saat ini Matematika masih dianggap mata pelajaran yang sulit, membosankan, bahkan menakutkan. Anggapan ini mungkin tidak berlebihan selain mempunyai sifat yang abstrak, Matematika juga memerlukan pemahaman konsep yang baik, karena untuk memahami konsep yang baru diperlukan prasyarat pemahaman konsep sebelumnya.

Menurut Anas Sudijono (2006:

50) pemahaman adalah kemampuan seseorang untuk mengerti atau memahami sesuatu setelah sesuatu itu diketahui dan diingat. Seorang peserta didik dikatakan memahami sesuatu apabila ia dapat memberikan penjelasan atau memberi uraian yang lebih rinci tentang hal itu dengan menggunakan kata-katanya sendiri.

Dalam mempelajari Matematika , pemahaman konsep Matematika sangat penting untuk siswa. Karena konsep Matematika yang satu dengan yang lain berkaitan sehingga untuk mempelajarinya harus runtut dan berkesinambungan. Jika siswa telah memahami konsep-konsep Matematika maka akan memudahkan siswa dalam mempelajari konsep-konsep Matematika berikutnya yang lebih kompleks.

Berdasarkan hasil ulangan harian Matematika materi Himpunan bilangan Kelas VII .4 SMPN 1 Praya semester 1 dihasilkan data dan jumlah peserta ulangan 34 siswa yang tuntas belajar sebanyak 14 siswa atau sebesar $41 \%$ dan yang belum tuntas sebanyak 20 orang siswa atau sebesar $59 \%$,sedangkan KKM yang ditetapkan untuk pelajaran Matematika di SMPN 1 Praya sebesar 70 pada tahun pelajaran 2018 12019 dengan ketuntasan klasikal sebesar $\geq$ $80 \%$.

Ternyata penyebab rendahnya hasil belajar siswa disebabkan oleh ketidak 
tepatan penggunaan metode dalam menyampaikan materi yang mengenai Himpunan bilangan di kelas VII.4 dan guru tidak menggunakan media dalam proses pembelajaran, sehingga siswa merasa bosan dan cepat jenuh dan kurang konsentrasi dalam pembelajaran, kemudian juga siswa tidak dilibatkan dalam penemuan konsep sehingga pengetahuan anak tentang konsep himpunan menjadi dangkal. di tingkat SLTP anak dituntut mengerti tentang definisi, pengertian, cara pemecahan masalah maupun pengoperasian Matematika secara benar, karena akan menjadi bekal dalam mempelajari Matematika pada jenjang pendidikan yang lebih tinggi.

Sehingga peneliti menawarkan salah satu model pembelajaran yang mengaktifkan kerja kelompok kecil yaitu Model pembelajaran kooperatif adalah model pembelajaran yang lebih mengedepankan siswa pada kerja kelompok , mampu meningkatkan semangat siswa dalam memahami konsep Matematika dan dapat mempermudah siswa belajar Matematika sehingga dapat meningkatkan pemahaman konsep Matematika siswa.

Model pembelajaran kooperatif tipe STAD merupakan pilihan peneliti yang akan digunakan dalam penelitian ini. Dengan model pembelajaran kooperatif tipe STAD akan tercipta kerjasama dan keberhasilan dalam kelompok yang tergantung dari keberhasilan individu.

Dengan demikian memungkinkan terciptanya suasana belajar yang menyenangkan bagi siswa, menumbuhkan rasa kepemilikan siswa terhadap kegiatan pembelajaran, meningkatkan interaksi dan kerjasama diantara siswa untuk bersama-sama meningkatkan hasil belajar, meningkatkan komunikasi dan interaksi dengan guru dan menciptakan situasi pembelajaran yang kondusif dan mengajar siswa untuk berfikir kritis.

Berdasarkan analisis situasi pembelajaran Matematika di SMPN 1 Praya kami akan mengangkat judul penelitian Tindakan kelas yaitu "Meningkatkan Hasil Belajar Matematika Materi Himpunan Bilangan dengan Pembelajaran Kooperatif
Tipe Student Teams Achievement Division (STAD) pada Siswa Kelas VII.4 SMPN 1 Praya Tahun pelajaran 2018 /2019"

\section{Rumusan Masalah}

Berdasarkan uraian di atas, penulis dapat mengemukakan rumusan masalah dalam penelitian ini sebagai berikut" Bagaimanakah Meningkatkan Hasil Belajar Matematika Materi Himpunan Bilangan dengan Pembelajaran Kooperatif Tipe Student Teams Achievement Division (STAD) pada Siswa Kelas VII.4 SMPN 1 Praya Tahun pelajaran $2018 / 2019$ "

\section{Tujuan Penelitian}

Tujuan yang ingin dicapai dalam penelitian ini adalah : Untuk Meningkatkan Hasil Belajar Matematika Materi Himpunan Bilangan dengan Pembelajaran Kooperatif Tipe Student Teams Achievement Division (STAD) pada Siswa Kelas VII.4 SMPN 1 Praya Tahun pelajaran 2018 /2019"

\section{Manfaat Penelitian}

Membantu dan mempermudah siswa-siswi kelas VII.4 SMPN 1 Praya dalam memahami suatu konsep Matematika . Membantu dan melatih siswa agar membiasakan diri dalam kerja kelompok, dengan berdiskusi siswa dapat berfikir kritis.

\section{LANDASAN TEORI DAN KAJIAN PUSTAKA}

\section{Hakikat Matematika}

Matematika (dalam bahasa inggris mathematics) berasal dari perkataan latin mathematica, yang mulanya diambil dari perkataan Yunani, matematike, yang berarti "relating to learning". Perkataan ini mempunyai akar kata mathema yang berarti knowledge,science (pengetahuan, ilmu). Herman Hudojo (2005: 36) mengemukakan bahwa Matematika itu berkenaan dengan gagasan berstruktur yang hubunganhubungannya diatur secara logis. Ini berarti Matematika bersifat sangat abstrak. Yaitu brrkenaan dengan konsep-konsep abstrak dan penalaran deduktif.

Matematika menurut Ruseffendi yang dikutip oleh Eman Suherman (2003: 16) terbentuk sebagai hasil pemikiran manusia berhubungan dengan ide, proses dan penalaran. Pada tahap awal Matematika terbentuk dari pengalaman manusia dalam 
dunianya secara empiris, karena Matematika sebagai aktivitas manusia kemudian pengalaman itu diproses dalam dunia rasio, diolah secara analisis dan sintesis dengan penalaran di dalam struktur kognitif sehingga sampailah pada suatu kesimpulan berupa konsep-konsep Matematika . Agar konsepkonsep Matematika yang telah terbentuk itu dapat dipahami dan dapat dengan mudah dimanipulasi secara tepat, maka digunakan notasi dan istilah yang disepakati bersama secara global (universal) yang dikenal dengan istilah Matematika .

Dari pengertian dan karakteristik Matematika diatas, dapat disimpulkan bahwa Matematika merupakan ilmu sebagai sarana berfikir yang meliputi penalaran dan logika, serta objeknya meliputi fakta, konsep, ketrampilan dan aturan Matematika yang melatih kemampuan berfikir logis, analitis, ketelitian, ketekunan dan memecahkan masalah yang saling berhubungan satu sama lain serta bermanfaat dalam memahami ilmuilmu lain.

\section{Pembelajaran Matematika}

Menurut Saiful Sagala (2009: 61) pembelajaran ialah membelajarkan siswa menggunakan asas pendidikan maupun teori belajar merupakan penentu utama keberhasilan pendidikan. Pembelajaran merupakan proses komunikasi dua arah, mengajar dilakukan oleh guru sebagai pendidik, sedangkan belajar dilakukan oleh peserta didik atau murid.

Menurut Herman Hudojo (2005: 103) pembelajaran Matematika berarti pembelajaran tentang konsep-konsep dan struktur-struktur yang terdapat dalam bahasan yang dipelajari serta mencari hubunganhubungan antara konsep-konsep dan strukturstruktur tersebut. Sedangkan Dienes (Herman Hudojo, 2005: 71) mengemukakan bahwa belajar Matematika melibatkan suatu struktur hierarki dari konsep- konsep tingkat yang lebih tinggi yang dibentuk atas dasar apa yang telah terbentuk sebelumnya.

Dari uraian di atas dapat disimpulkan bahwa pembelajaran Matematika adalah tentang konsep-konsep dan strukturstruktur yang terdapat dalam Matematika yang pada akhirnya siswa dapat mengkomunikasikan konsep-konsep dan struktur-struktur tersebut sehingga proses belajar dapat berkembang secara optimal.

\section{Hakekat Belajar}

Belajar merupakan salah satu faktor yang mempengaruhi dan berperan penting dalam pembentukan pribadi dan perilaku individu. Nana Syaodih Sukmadinata (2005) menyebutkan bahwa sebagian terbesar perkembangan individu berlangsung melalui kegiatan

(http://www.scribd.com/doc/6439508/

Pengertian- BelajarLintang?autodown=pdf)

Belajar merupakan suatu proses aktif dalam memperoleh pengalaman/ pengetahuan baru sehingga menyebabkan perubahan tingkah laku (Herman Hudojo, 2005: 71).

Sedangkan Oemar Hamalik (2005: 28) mengemukakan bahwa belajar adalah suatu proses perubahan tingkah laku individu melalui interaksi dengan lingkungan.

Menurut Lester D. Crow yang dikutip oleh Saiful Sagala (2009: 13) belajar dikatakan berhasil manakala seseorang mampu mengulangi kembali materi yang telah dipelajarinya, maka belajar tersebut disebut "rote learning". Kemudian jika yang telah dipelajari tersebut mampu disampaikan dan diekspresikan dalam bahasa sendiri, maka disebut "overlearning".

$$
\text { Menurut Slameto (1995: }
$$

belajar adalah suatu proses usaha yang dilakukan seseorang untuk memperoleh suatu perubahan tingkah laku yang baru secara keseluruhan, sebagai hasil pengalamannya sendiri dalam interaksi dengan lingkungannya.

Teori psikologi Gestalt tentang belajar, mendefinisikan bahwa belajar siswa mengutamakan aspek pemahaman (insight). Pemahaman adalah kemampuan melihat hubungan berbagai faktor atau unsur dalam situasi yang problematis (Oemar Hamalik, 2005: 41).

Dari beberapa teori di atas dapat disimpulkan bahwa belajar adalah suatu proses aktif dalam memperoleh pengalaman dan pengetahuan baru dan mengutamakan aspek pemahaman sehingga menyebabkan perubahan tingkah laku individu melalui 
interaksi antar individu dengan individu maupun dengan lingkungan.

\section{Pemahaman Konsep}

Konsep adalah suatu ide abstrak yang memungkinkan kita mengklasifikasikan objek-objek atau peristiwa-peristiwa itu termasuk atau tidak ke dalam ide abstrak tersebut (Herman Hudojo, 2003: 124). Sedangkan konsep menurut Winkel (2004: 92) adalah satuan arti yang mewakili sejumlah objek yang memiliki ciri-ciri yang sama.

Kemampuan tersebut mencakup tiga hal yaitu, translasi yang mencakup penerjemahan pengetahuan atau gagasan dari bentuk abstrak ke bentuk konkret atau sebelumnya, interpretasi yang mencakup kemampuan untuk mencirikan merangkum pikiran utama dari suatu gagasan, serta

ektrapolasi yang mencakup kemampuan untuk menterjemahkan, mengartikan serta menyelesaikan masalah.

\section{Pembelajaran Kooperatif}

Slavin (2005: 4) mengemukakan bahwa pembelajaran kooperatif adalah berbagai macam metode pembelajaran di mana para siswa bekerja dalam kelompokkelompok kecil yang memiliki tingkat kemampuan yang berbeda untuk saling membantu satu sama lainnya dalam mempelajari materi pelajaran. Dalam kelas kooperatif, siswa diharapkan dapat saling membantu, saling mendiskusikan dan berargumentasi, untuk mengasah pengetahuan yang mereka kuasai saat itu dan menutup kesenjangan dalam pemahaman masingmasing.

\section{Pembelajaran Kooperatif Tipe Student Team Achievement Division (STAD)}

STAD merupakan salah satu model pembelajaran kooperatif yang paling sederhana. Sehingga model pembelajaran ini dapat digunakan oleh guru-guru yang baru memulai menggunakan pendekatan pembelajaran kooperatif (Slavin, 2008: 143).

STAD dikembangkan oleh Robert E.Slavin dan teman- temannya di Universitas John Hopkin. Dalam STAD, para siswa dibagi dalam tim belajar yang terdiri atas empat orang yang berbeda beda tingkat kemampuan, jenis kelamin, dan latar belakang etniknya. Guru menyampaikan pelajaran, lalu siswa bekerja dalam tim mereka untuk memastikan bawa semua anggota tim telah menguasai pelajaran. Selanjutnya, semua siswa mengerjakan kuis mengenai materi secara sendiri-sendiri, di mana saat itu mereka tidak diperbolehkan untuk saling membantu (Slavin, 2008: 11-13)

Skor kuis para siswa dibandingkan dengan rata-rata pencapaian mereka sebelumnya, dan kepada masingmasing tim akan diberikan point berdasarkan tingkat kemajuan yang diraih siswa dibandingkan hasil yang mereka capai sebelumnya. Poin ini kemudian dijumlahkan untuk memperoleh skor tim, dan tim yang berhasil memenuhi kriteria tertentu akan mendapatkan penghargaan.

\section{Pengertian Himpunan}

Himpunan adalah kumpulan benda-benda yang didefinisikan dengan jelas. Objek-objek dari himpunan yang didefinisikan dengan jelas yaitu suatu objek yang dapat ditentukan dengan pasti termasuk dalam himpunan tersebut atau tidak. Pada umumnya himpunan disimbolkan dengan huruf kapital A, B, C, .... Objek dalam himpunan disebut elemen/ anggota himpunan yang disimbolkan dengan huruf alfabet kecil $\mathrm{a}, \mathrm{b}, \mathrm{c}, \ldots$.

\section{METODE PENELITIAN}

Jenis penelitian ini adalah Penelitian Tindakan Kelas (PTK) yang dilakukan secara kolaboratif antara peneliti dengan guru Matematika kelas VII .4 SMPN 1 Praya Pada tahap awal guru dan peneliti mendiskripsikan permasalahan penelitian dan menentukan rencana tindakan. Rencana tindakan yang telah disusun bersama, kemudian dipraktikan oleh guru saat melakukan pembelajaran di kelas. Pada saat guru melakukan pembelajaran, peneliti berada di kelas yang sama dan mencatat segala sesuatu yang terjadi saat pembelajaran.

\section{Subyek Penelitian}

Subyek penelitian ini adalah siswa kelas VII. 4 SMPN 1 Praya yang berjumlah 34 orang yang terdiri dari 16 orang laki - laki dan 18 orang perempuan, sebagian besar siswa berasal dari kota Praya.

Tempat dan Waktu Penelitian 
Penelitian dilaksanakan di kelas VII.4 SMPN 1 Praya yang terletak di Jalan M. Yamin No 1 Praya. penilitian ini akan dilaksanakan pada semester genap tahun pelajaran 2018 /2019. Mulai dari bulan Januari sampai dengan bulan Maret 2019.

\section{Setting Penelitian}

Setting penelitian yang digunakan dalam penelitian ini adalah setting kelas dalam kegiatan pembelajaran Matematika yang dilaksanakan di kelas VII .4 SMPN 1 Praya pada materi himpunan.

\section{Rancangan Penelitian}

Penelitian ini menggunakan model spiral yang dikembangkan oleh Kemmis dan Taggart .Dalam model ini terdapat empat tahapan yang haru dilakukan yaitu perencanaan tindakan , observasi, dan refleksi. Berikut bagan dari model spiral Kemmis dan Taggart yang diambil dari Rochiati Wiriaatmadja (2005: 66) :

Adapun rancangan penelitian tindakan ini yang akan dilaksanakan pada setiap siklusnya terdiri dari: (1) Perencanaa tindaakan, (2) Pelaksanaan Tindakan, (3) Observasi (Pengamatan) , (4) Tahap Refleksi.l

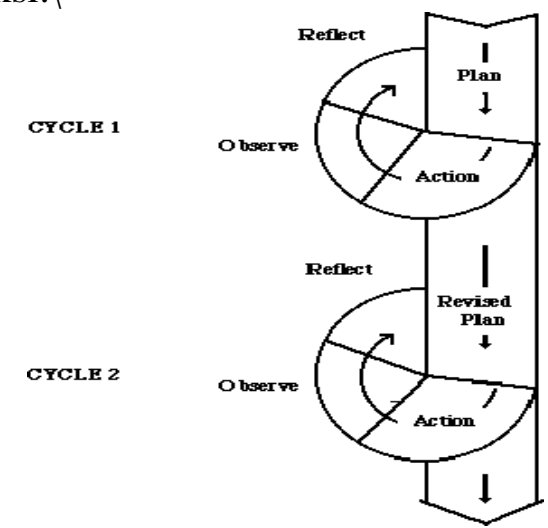

dan Mc Taggart

Gbr;Model Spiral dari Kemmis

\section{Instrumen Penelitian}

Istrumen yang digunakan dalam penelitian ini adalah Tes Tertulis. Tes tertulis pada umumnya digunakan untuk menilai dan mengukur hasil belajar siswa, terutama hasil belajar kognitif berkenaan dengan pemahaman dan penguasaan bahan pengajaran yang sesuai dengan tujuan pelajaran (Nana Sudjana, 2005: 35).. Hasil tes ini akan menunjukkan kemampuan siswa dalam memahami materi Himpunan

\section{Dokumentasi.}

Peneliti menggunakan dokumentasi berupa rekaman foto yang digunakan sebagai alat pencatatan untuk membantu kegiatan observasi. Rekaman foto ini digunakan untuk membantu menggambarkan apa yang terjadi di kelas pada waktu pembelajaran berlangsung.

\section{Teknik pengumpulan data}

Teknik yang digunakan dalam pengumpulan data adalah sebagai berikut: (1) Tes Tertulis, (2) Dokumentasi, Kegiatan ini bertujuan untuk mengungkapkan fakta atau kenyataan pada saat pelaksanaan tindakan.

\section{Teknik Analisis Data}

Data yang diperoleh dalam penelitian ini berupa lember observasi proses pembelajaran, tes hasil belajar. Teknik analisis data dalam penelitian ini adalah analisis dekstriptif untuk mengetahui pelaksanaan dan hambatan- hambatan yang terjadi dalam pembelajaran dengan model pembelajaran kooperatif tipe STAD dan analisis kuantitatif untuk mengethui peningkatan pemahaman konsep Matematika siswa.

Untuk menganalisi tingkat keberhasilan atau peresentase keberhasilan siswa setelah proses belajar mengajar setiap siklus nya dilakukan dengan cara memberikan evaluasi berupa soal tes tertulis paa setiap akhir siklus, Analisi ini dihitung dengan menggunakan statistik sederhana yaitu :

formatif

Untuk menilai ulangan atau tes

Peneliti melakukan penjumlahan nilai yang diperoleh siswa, yang selanjutnya dibagi dengan jumlah siswa yang ada di kelas tersebut sehingga diperoleh rata-rata tes formatif dapat dirumuskan :

$$
\begin{array}{ll}
\overline{\mathrm{X}}=\frac{\Sigma x}{\Sigma \mathrm{N}} & \\
\text { Dengan } & : \overline{\mathrm{X}}=\begin{array}{l}
=\text { Nilai rata-rata } \\
=\text { Jumla semua }
\end{array} \\
\text { nilai siswa } & \sum \mathrm{X} \quad
\end{array}
$$

Untuk ketuntasan belajar

$$
\sum \mathrm{N}=\text { Jumlah siswa }
$$

Ada dua kategori ketuntasan belajar yaitu secara perorangan dan secara klasikal. Berdasarkan petunjuk pelaksanaan belajar mengajar kurikulum 2018 yaitu seorang siswa telah tuntas belajar bila telah mencapai skor $70 \%$ atau nilai 70 , dan kelas 
disebut tuntas belajar apa bila di kelas tersebut terdapat $80 \%$ yang telah mencapai daya serap lebih dari atau sama dengan $80 \%$. Untuk menghitung presentase ketuntasan belajar digunakan rumus sebagai berikut :

$\mathrm{P}=\frac{\Sigma x}{\Sigma \mathrm{N}} \times 100 \%$

Keterangan

$\mathrm{P} \quad=$ Prosentase ketuntasan kelas

$\sum X=$ Jumla semua nilai siswa

$\sum \mathrm{N}=$ Jumlah siswa

HASIL PENELITIAN DAN

PEMBAHASAN

\section{Pelaksanaan}

tindakan

pembelajaran dengan model pembelajaran kooperatif tipe Student Team Achievement Divisions (STAD) dilakukan selama tiga siklus. Masing-masing siklus dilaksanakan satu kali pertemuan dengan alokasi waktu selama 2 x 40 menit dan satu kali pertemuan selama 1 x 40 menit untuk tes akhir siklus. Pada siklus pertama topik yang diajarkan mengenai himpunan bagian dan irisan gabungan himpunan, pada siklus kedua topik yang diajarkan sama dengan siklus satu dengan penekanan pada pemahaman konsep

Berikut ini penjabaran kegiatankegiatan pembelajaran yang dilaksanakan pada masing-masing siklus.

\section{Siklus I}

Untuk memperoleh gambaran dari hasil penelitian diperlukan data. Data tersebut adalah sejumlah fakta yang digunakan sebagai sumber atau masukan untuk menentukan kesimpulan yang diambil yang menjadi topik pengamatan adalah kegiatan siswa, Kegiatan guru dan hasil pembelajaran siswa pada mata pelajaran Matematika di kelas VII.4 SMPN 1 Praya Pada Materi Himpunan Bilangan

Adapun prosedur yang dilakukan dalam setiap siklus penelitian melalui tahapan-tahapan seperti berikut; perencanaan, (2) pelaksanaan, pengamatan, (4) refleksi dan refisi

Berdasarkan hasil pengolahan nilai pada siklus 1 masih belum menunjukkan hasil yang memuaskan, bahwa kemampuan siswa dalam memahami materi pembelajaran Matematika pada materi Himpunan masih belum mencapai KKM yang telah di tetapkan yaitu 70 untuk mata pelajaran Matematika tahun pelajaran 2018 /2019. Hasil belajar siswa terhadap materi pelajaran Himpunan belum maksimal dari hasil tes di peroleh 21 siswa atau $62 \%$ dan sebanyak 13 orang siswa belum tuntas belajar atau sebesar $38 \%$ ,Hasil tersebut menunjukkan bahwa pada siklus pertama secara klasikal siswa belum tuntas belajar, karena siswa yang memperoleh nilai $\geq 70$ hanya sebesar $62 \%$ lebih kecil dari persentase ketuntasan yang dikehendaki yaitu sebesar $\geq 80 \%$. Hal ini disebabkan karena siswa masih merasa baru dan belum mengerti apa yang dimaksudkan dan digunakan guru dengan menerapkan metode belajar Kooperatif tipe STAD

\section{Siklus II}

Pada siklus ii setelah dilakukan pengolahan nilai diperoleh nilai rata-rata hasil belajar siswa sebesar 81,64, jumlah siswa yang tuntas belajar sebanyak 31 orang dari 34 siswa dengan persentase sebesar $91 \%$ dan jumlah siswa yang belum tuntas sebanyak 3 orang dengan persentase sebesar 9 $\%$. Hasil ini menunjukkan bahwa pada siklus II ini ketuntasan belajar secara klasikal telah mengalami peningkatan yang signifikan dari siklus I, dan mencapai ketuntasan klasikal yang diharapkan yaitu $\geq 80 \%$. Adanya peningkatan hasil belajar siswa ini karena karena siswa sudah merasa senang dengan metode pembelajaran matematika yang diterapkan oleh guru, dan setiap akhir pelajaran akan selalu diadakan tes sehingga siswa termotivasi untuk belajar. Selain itu siswa juga sudah mulai mengerti apa yang dimaksudkan dan dinginkan guru dengan menerapkan metode belajar Kooperatif tipe STAD.

\section{Pembahasan}

\section{Ketuntasan Hasil belajar Siswa}

Melalui hasil penelitian ini menunjukkan bahwa Pembelajaran Kooperatif Tipe STAD memiliki dampak positif dalam meningkatkan prestasi belajar siswa. Hal ini dapat dilihat dari semakin mantapnya pemahaman siswa terhadap materi yang disampaikan guru, dilihat dari hasil belajar yang diperoleh dari siklus I sampai siklus II terus menunjukkan peningkatan hasil belajar yang signifikan.

Hasil belajar pada siklus 1 masih 
belum menunjukkan hasil yang memuaskan, bahwa kemampuan siswa dalam memahami materi pembelajaran Matematika pada materi Himpunan masih belum mencapai KKM yang telah di tetapkan yaitu 70 untuk mata pelajaran Matematika tahun pelajaran 2018 /2019. Hasil belajar siswa terhadap materi pelajaran Himpunan belum maksimal dari hasil tes di peroleh 21 siswa atau 62\% dan sebanyak 13 orang siswa belum tuntas belajar atau sebesar $38 \%$,Hasil tersebut menunjukkan bahwa pada siklus pertama secara klasikal siswa belum tuntas belajar, karena siswa yang memperoleh nilai $\geq 70$ hanya sebesar $62 \%$ lebih kecil dari persentase ketuntasan yang dikehendaki yaitu sebesar $\geq$ $80 \%$. Hal ini disebabkan karena siswa masih merasa baru dan belum mengerti apa yang dimaksudkan dan digunakan guru dengan menerapkan metode belajar Kooperatif tipe STAD

Kemudian hasil belajar pada siklus II diperoleh nilai rata-rata sebesar 81,64 , jumlah siswa yang tuntas belajar sebanyak 31 orang dengan persentase sebesar $91 \%$ dan jumlah siswa yang belum tuntas sebanyak 3 orang dengan persentase sebesar 9 $\%$. Hasil ini menunjukkan bahwa pada siklus II ini ketuntasan belajar secara klasikal telah mengalami peningkatan yang signifikan dari siklus I, dan mencapai ketuntasan klasikal yang diharapkan yaitu $\geq 80 \%$. Adanya peningkatan hasil belajar siswa ini karena karena siswa sudah merasa senang dengan metode pembelajaran matematika yang diterapkan oleh guru, dan setiap akhir pelajaran akan selalu diadakan tes sehingga siswa termotivasi untuk belajar. Selain itu siswa juga sudah mulai mengerti apa yang dimaksudkan dan dinginkan guru dengan menerapkan metode belajar Kooperatif tipe STAD.

Dari kedua data yang diperoleh terlihat peningkatan hasil belajar yang signifikan, dimana pada siklus I diperoleh nilai rata - rata sebesar 66,55 kemudian meningkat pada siklus II nilai rata - rata diperoleh sebesar 81, 64 terjadi peningkatan sebesar 15 poin, kemudian pada siklus I jumlah siswa yang tuntas belajar sebanyak 21 orang atau dengan persentase sebesar $62 \%$, kemudian meningkat pada siklus II jumlah siswa yang tuntas belajar sebanyak 31 orang dengan persentase sebesar $91 \%$ terjadi peningkatan sebesar 53 poin, begitu juga dengan ketuntasan klasikal yang dipatok sebesar $\geq 80 \%$ juga sudah tercapai, sehingga penelitian ini dihentikan sampai pada siklus II.

Dengan demikian dapat ditarik kesimpulan bahwa dengan penerapan model pembelajaran kooperatif tipe Student Team Achievement Divisions (STAD) dapat meningkatkan hasil belajar Matematika materi himpunan pada siswa kelas VII.4 SMPN 1 Praya Tahun Pelajaran 2018 /2019.

\section{PENUTUP}

Melalui hasil penelitian ini menunjukkan bahwa Pembelajaran Kooperatif Tipe STAD memiliki dampak positif dalam meningkatkan prestasi belajar siswa. Hal ini dapat dilihat dari semakin mantapnya pemahaman siswa terhadap materi yang disampaikan guru, dilihat dari hasil belajar yang diperoleh dari siklus I sampai siklus II terus menunjukkan peningkatan hasil belajar yang signifikan.

Dari kedua data yang diperoleh terlihat peningkatan hasil belajar yang signifikan, dimana pada siklus I diperoleh nilai rata - rata sebesar 66,55 kemudian meningkat pada siklus II nilai rata - rata diperoleh sebesar 81, 64 terjadi peningkatan sebesar 15 poin, kemudian pada siklus I jumlah siswa yang tuntas belajar sebanyak 21 orang atau dengan persentase sebesar $62 \%$, kemudian meningkat pada siklus II jumlah siswa yang tuntas belajar sebanyak 31 orang dengan persentase sebesar $91 \%$ terjadi peningkatan sebesar 53 poin, begitu juga dengan ketuntasan klasikal yang dipatok sebesar $\geq 80 \%$ juga sudah tercapai, sehingga penelitian ini dihentikan sampai pada siklus II.

Dengan demikian dapat ditarik kesimpulan bahwa dengan penerapan model pembelajaran kooperatif tipe Student Team Achievement Divisions (STAD) dapat meningkatkan hasil belajar Matematika materi himpunan pada siswa kelas VII.4 SMPN 1 Praya Tahun Pelajaran 2018 /2019. 
Arikunto, Suharsimi. 2005. Dasar-Dasar Evaluasi Pendidikan. Jakarta:Bumi Aksara.

Budijastuti, Widowati. 2001. Strategi Pembelajaran Dalam Pelatihan. Surabaya: Universitas Negeri Surabaya

Departemen Pendidikan Nasional. 2003. Standar Kompetensi Mata Pelajaran Matematika SMP \& MTs Jakarta: Pusat Kurikulum, Balitbang Depdiknas.

Dick, W \& Carey, L. 1985. The Sistematic Design of Instruction. Illionis, CH: Scott, Foreman \& Company.

Dinas Pendidikan Kabupaten Sidoarjo. 2006. Materi Pengembangan Profesi Guru Tahun 2006. Sidoarjo: Dinas Pendidikan Kabupaten Sidoarjo

Djamarah, Syaiful Bahri. 2000. Guru dan Anak Didik dalam Interaksi Edukatif. Jakarta. Bumi Aksara.

Djamarah, Syaiful Bahri. 2002. Psikologi Belajar.Jakarta. PT Rineka Cipta.

Hamalik, Oemar. 2008. Pendidikan Guru Berdasarkan Pendekatan Kompetensi. Bumi Aksara.

J.Alder, Montimer dan Van Doren, Charles. 2006. How to Read a book, cara jitu mencapai puncak tujuan membaca. Jakarta: iPublishing

Mulyasa. 2005. Kurikulum Berbasis Kompetensi Konsep Karakteristik dan

Implementasi. Bandung: Remaja Rosda Karya.

Mulyasa. 2008. Implementasi Kurikulum Tingkat Satuan Pelajaran. Bumi Aksara.

M. Cholik A dan Sugijono. 2007. Matematika untuk SMP Kelas VII. Jakarta Erlangga.

Roestiyah. 2001. Strategi Belajar Mengajar. Jakarta: PT Rineka Cipta.

Rohani, Ahmad. 2004. Pengelolaan Pengajaran. Jakarta: PT Rineka Cipta.

Sadiman, Arief Sukadi. 2006. Media Pendidikan: Pengertian, Pengembangan, dan Pemanfaatannya. Jakarta: Raja
Grafindo Persada.

Sekolah Indonesia. 2005. Mading. http://www.sekolahindonesia.com

/sidev /mading

/mading.asp?iid_mading=72\&iid Sekolah $=1$

Sugiono. 2004. Statistika untuk Penelitian. Bandung: Alfabeta

Sukino dan Wilson Simangunsong. 2007. Matematika SMP Jilid I Kelas VII. Jakarta : Erlangga

Tatag Yuli Eko Siswono dan Netti Lastiningsih. 2007. Matematika SMP dan MTs untuk KelasVII. Jakarta : Erlangga 